\title{
Biodiversity and structure of spider communities along a metal pollution gradient
}

\author{
Sebatian Żmudzki • Ryszard Laskowski
}

Accepted: 5 April 2012/Published online: 28 April 2012

(c) The Author(s) 2012. This article is published with open access at Springerlink.com

\begin{abstract}
The objective of the study was to determine whether long-term metal pollution affects communities of epigeal spiders (Aranea), studied at three taxonomic levels: species, genera, and families. Biodiversity was defined by three indices: the Hierarchical Richness Index (HRI), Margalef index $\left(\mathrm{D}_{\mathrm{M}}\right)$ and Pielou evenness index $(\mathrm{J})$. In different ways the indices describe taxa richness and the distribution of individuals among taxa. The dominance pattern of the communities was described with four measures: number of dominant species at a site, percentage of dominant species at a site, average dominant species abundance at a site, and the share of the most numerous species (Alopecosa cuneata) at a site. Spiders were collected along a metal pollution gradient in southern Poland, extending ca. $33 \mathrm{~km}$ from zinc and lead smelter to an uncontaminated area. The zinc concentration in soil was used as the pollution index. The study revealed a significant effect of metal pollution on spider biodiversity as described by HRI for species $(p=0.039)$, genera $(p=0.0041)$ and families $(p=0.0147)$, and by $\mathrm{D}_{\mathrm{M}}$ for genera $(p=0.0259)$ and families $(p=0.0028)$. HRI correlated negatively with pollution level, while $\mathrm{D}_{\mathrm{M}}$ correlated positively. This means that although broadly described HRI diversity decreased with increasing pollution level, species richness increased with increasing contamination. Mesophilic meadows were generally richer. Pielou ( $\mathrm{J})$ did not show any significant correlations. There were a few evidences for the intermediate disturbance hypothesis: certain indices reached their
\end{abstract}

\footnotetext{
S. Żmudzki ( $₫) \cdot$ R. Laskowski $(\bowtie)$

Institute of Environmental Sciences, Jagiellonian University, ul. Gronostajowa 7, 30-387 Kraków, Poland

e-mail: sebastian.zmudzki@uj.edu.pl

R. Laskowski

e-mail: ryszard.laskowski@uj.edu.pl
}

highest values at moderate pollution levels rather than at the cleanest or most polluted sites.

Keywords Metals pollution - Biodiversity - Epigeic spiders · Soil pollution - Intermediate disturbance hypothesis $\cdot$ Domination patterns

\section{Introduction}

Intensive mining, metallurgy, and in previous decades the use of leaded petrol, have made contamination by a range of trace metals a common phenomenon of many industrial and urban areas. Some of these metals are not used by most organisms for any purpose and are toxic at even relatively small concentrations (e.g., $\mathrm{Pb}, \mathrm{As}$ ). Other play vital physiological roles (e.g., $\mathrm{Zn}, \mathrm{Cu}, \mathrm{Fe}, \mathrm{Mn}$ ) but can also be harmful when they exceed optimal concentrations. Trace metals, like other stress factors, may thus affect the natural environment, starting from effects at the level of single individuals and potentially extending to whole ecosystems. In terrestrial ecosystems, soils affected by metals have lower organic matter decomposition rates (Niklińska et al. 1998; Tyler 1976), which can lead to immobilization and accumulation of vital microelements (Giller et al. 1998), a large portion of which becomes unavailable to the first level of trophic chains-plants. This can drastically alter the productivity of plants and ecosystems (Gallagher et al. 2008) and the availability of microelements for higher trophic levels. In animals, metals affect their metabolism, physiology and life histories, and as a result may seriously compromise their fitness (Fountain and Hopkin 2004a; Kramarz and Laskowski 1997; Łagisz et al. 2002; Możdżer et al. 2003; Posthuma and van Stralen 1993; Sibly and Calow 1989). Changes in the fitness of particular species 
influence basic interspecies relationships (competition, predation, parasitism), and this may have serious implications for higher levels of organization-populations, communities and ecosystems (Clements and Newman 2002). Indeed, Salminen et al. (2001) showed that metal pollution can destabilize the functioning of whole ecosystems through its impact on keystone species or keystone groups: zinc contamination prevented the keystone enchytreid Cognettia sphagnetorum from reaching high population density and consequently led to lower microbial-mediated soil decomposition rates and soil productivity.

The epigeal spiders studied here are among the most abundant representatives of the predators' guild on forest and meadow floors (Marc and Canard 1997) and in other environments (Duelli and Obrist 1998). They represent the second trophic level of consumers in food webs and play a crucial role in herbivore and detritivore food webs (Foelix 1996; Jung et al. 2008a). Spiders are responsible for regulation of herbivore populations, including many pests, and their absence or decrease in numbers may disturb the trophic structure and lead to excessive herbivory (Haughton et al. 1999; Kajak et al. 1968; Marc et al. 1999). For example, pest abundance was significantly lower in corn fields treated with push-pull habitat management applying higher spider richness and abundance. This novel treatment employing arthropods can serve as an alternative to synthetic insecticides (Midega et al. 2008). On the other hand, spiders are an important food source for bigger animals like birds, small mammals, amphibians, and small reptiles (Foelix 1996; Marc et al. 1999).

Spider communities - their structure, abundance and richness-are useful and recommended indicators of whole-biocenosis biodiversity (Willet 2001). Their richness correlates with the abundance of other animals (gastropods, orthopterans, carabids, birds) and can be applied in conservation ecology and assessment of environmental changes (Duelli and Obrist 1998; Sauberer et al. 2004). At the same time, spider richness and abundance strongly depend on the condition and structure of the flora (e.g., Oxbrough et al. 2007; Sauberer et al. 2004), landscape structure and landscape disturbances (Schmidt et al. 2008; Willet 2001). The vegetation-its type, height and composition-plays a vital role in ecosystems, influencing their microclimate and determining the herbivorous species community, the main source of spiders' prey. The variability of prey, with their different life strategies, influences the diversity of spiders, which are not a strictly homogenous group of predators. There are two basic hunting strategies: "sit and wait", and active hunting (and there are many variants). Spider species have different styles of hunting, and they hunt for different kinds of prey (Marc and Canard 1997, Marc et al. 1999). Thanks to this, their diversity can reflect the diversity of other trophic levels, indicating the spiders' victims and the victims' food source. Yet another advantage of using this group of predators as a diversity indicator is that they are easy to collect and the sampling techniques are simple and cheap (Jung et al. 2008a; Kapoor 2008).

Spiders also make good indicators for ecotoxicological studies. They have been shown to accumulate the highest concentrations of many trace metals among all terrestrial invertebrates (Hendrickx et al. 2004; Laskowski and Kammenga 2000). When intoxicated with metals they exhibit strong physiological reactions to the intoxication, for example by having elevated levels of detoxifying enzymes (Babczynska et al. 2006; Wilczek et al. 2003, 2004), which may lead to shifts in their energy budgets. Despite these potential advantages as indicators of contamination, the biodiversity of this group has not been assayed very often in polluted areas, and there are not many papers addressing this problem. Gargasz (2007) found a strong negative impact of elevated metal concentrations on spider abundance and biodiversity in the vicinity of a copper smelter in Poland and a nickel smelter in the United Kingdom. On the other hand, Jung et al. (2008a) demonstrated rather small differences in spider diversity and community composition in response to cadmium and lead pollution in a moderately polluted area in Korea. In other animals the biodiversity patterns in contaminated areas are not consistent either. For example, Creamer at al. (2008) showed that the abundance of earthworms (Lumbricidae) was reduced in response to copper contamination, Enchytreidae and Nematoda appeared sensitive to both copper and zinc, and Collembola only to zinc. Tischer (2005) reported decreased earthworm biodiversity and biomass in copper-contaminated areas, and Lukkari et al. (2003) found similar effects in response to pollution with a mixture of metals. In the area covered here, Skalski et al. (2010) showed earlier that the abundance and diversity of ground beetles (Carabidae) decreased with increasing metal pollution. In contrast, no such trend was found for oribatid mites (Skubala and Kafel 2004).

In this study we investigated the impact of long-term metal pollution on communities of epigeal spiders. We used standard biodiversity indices to define richness patterns and describe dominance structure.

\section{Materials and methods}

Sites, fieldwork and laboratory work

The study area is located in the Olkusz region (S. Poland), which is naturally rich in zinc and lead ores; mining and smelting activity there dates back to medieval times. The whole region has elevated soil concentrations of a number of metals, especially $\mathrm{Zn}, \mathrm{Pb}$, and $\mathrm{Cd}$. The really serious 
pollution occurred in the 1970s when Poland's largest Polish zinc-and-lead smelter, Bolesław, constructed in the 1960s, reached peak production and peak emissions. Although robust measures were undertaken to control emissions in 1980 and later, a large area in close proximity to the smelter and mines remains highly polluted with metals. The highest recently reported surface soil concentrations (mg kg${ }^{-1}$ dry mass) were $6151 \mathrm{Zn}, 71.4 \mathrm{Cd}, 2206$ $\mathrm{Pb}, 54.5 \mathrm{Cu}$ and $18.6 \mathrm{Ni}$ in forests, and $2229 \mathrm{Zn}, 20.3 \mathrm{Cd}$, $814 \mathrm{~Pb}, 49.3 \mathrm{Cu}$ and $79.5 \mathrm{Ni}$ in meadows (Stefanowicz et al. 2008). Zinc levels are elevated as far as $15-20 \mathrm{~km}$ from the smelter (Table 1).

For this study we demarcated two meadow transects along the pollution gradient. Since the organisms of different habitats might respond to metal pollution differently, we established one transect on xerothermic meadow (6 sites, MX1 to MX6) and another on mesophilic meadow (5 sites, MM2 to MM6). These meadow types are representative for this region and differ in abiotic (humidity, temperature, soil permeability) and biotic (vegetation type) conditions. Xerothermic meadows are considered harsher environments: they are drier and warmer, with larger daily temperature amplitudes, and are less fertile than mesophilic meadows, which are usually described as more benign.

Metal concentrations in the soil at all study sites were determined earlier by Stefanowicz et al. (2008). The Zn concentrations are reported in Table 1 . The reference site for xerothermic meadow is ca. $20 \mathrm{~km}$ from the pollution source, and the one for mesophilic meadow ca. $33 \mathrm{~km}$ from it (Table 1).

At each site a rectangular sampling plot measuring $5 \times 10 \mathrm{~m}$ was established, and 66 Barber pitfall traps were placed $1 \mathrm{~m}$ apart in the plot. The traps were $150 \mathrm{ml}$ plastic vendor cups half-filled with preserving liquid (ethane-1,2- diol, Petrygo and Borygo automotive antifreeze, Poland). Material from all traps at each site was pooled in one container to make one sample.

Sampling was done six times in 2006: 10, 21 and 27 May, and 3, 11 and 27 June. Sampling was done in May and June because spring and early summer is the time of highest activity of terrestrial spiders. It is the mating season. The males are roaming and seeking females, and the females are looking for suitable hideouts where they can stay later with cocoons. At site MX3 no sample was obtained on May 27 because the pitfall traps had been destroyed, so 65 samples were collected in total. Material collected from each site during the whole sampling period was considered one sample. All collected samples were put into containers with ethanol and refrigerated for taxonomic identification. In the laboratory the spiders were separated from other material and counted. Mature individuals were identified to species level using available sources (Nentwig et al. 2011; Nieuwenhuys 2011; Platnick 2011; Roberts 1995). Because it is hardly possible to identify species in juveniles, all juveniles were considered one group, and in further biodiversity analysis only mature spiders were used. Such a procedure does not change the final results significantly (Sackett et al. 2008).

\section{Biodiversity measures and dominance structure}

On the basis of species identification, for each taxonomic level (species, genus, family) three biodiversity indices were calculated: Hierarchical Richness Index (HRI), Margalef index $\left(\mathrm{D}_{\mathrm{M}}\right)$ and Pielou evenness index $(\mathrm{J})$. The Pielou index measures how evenly individuals are distributed among taxa in a community, $\mathrm{D}_{\mathrm{M}}$ reports the number of species corrected for sample abundance, and HRI

Table 1 Characteristics of research sites, and abundance of collected mature and juvenile spiders

\begin{tabular}{|c|c|c|c|c|c|c|}
\hline Site code & $\begin{array}{l}\text { Distance from } \\
\text { smelter }(\mathrm{km})\end{array}$ & $\begin{array}{l}\mathrm{Zn} \text { concentration in } \\
\text { soil }\left(\mathrm{mg} \mathrm{kg}^{-1}\right)\end{array}$ & $\begin{array}{l}\text { Coded } \mathrm{Zn} \\
\text { concentration }\end{array}$ & $\begin{array}{l}\text { Mature spider } \\
\text { abundance }\end{array}$ & $\begin{array}{l}\text { Juvenile spider } \\
\text { abundance }\end{array}$ & $\begin{array}{l}\text { Juvenile } \\
\text { proportion (\%) }\end{array}$ \\
\hline MX1 & 1.9 & 1350 & 1.396 & 459 & 106 & 23.09 \\
\hline MX2 & 3.7 & 390 & 0.856 & 1027 & 107 & 10.42 \\
\hline MX3 & 4.0 & 390 & 0.856 & 417 & 52 & 12.47 \\
\hline MX4 & 8.6 & 259 & 0.678 & 1653 & 83 & 5.02 \\
\hline MX6 & 32.9 & 85.5 & 0.197 & 942 & 64 & 6.79 \\
\hline MX5 & 20.0 & 54.3 & 0.000 & 1242 & 112 & 9.02 \\
\hline MM2 & 0.6 & 2229 & 1.416 & 1390 & 122 & 8.76 \\
\hline MM4 & 8.6 & 273 & 0.504 & 965 & 89 & 9.33 \\
\hline MM3 & 4.0 & 239 & 0.446 & 1435 & 104 & 7.25 \\
\hline MM5 & 20.0 & 145 & 0.229 & 1922 & 231 & 12.02 \\
\hline MM6 & 32.9 & 85.5 & 0.000 & 2683 & 61 & 2.25 \\
\hline
\end{tabular}

Coded $\mathrm{Zn}$ concentration $=\log$-transformed concentration minus the lowest value from MX or MM transect (see Methods for details) $M X$ xerothermic meadow, $M M$ mesophilic meadow 
summarizes both aspects of community structure in one comprehensive measure and is recommended specifically for ecotoxicological research (French and Lindley 2000). It takes into account the number of species, their abundance, and the distribution of individuals among taxa. All indices were calculated with Excel spreadsheet, and are defined with the following formulae:

$H R I=\sum_{i=1}^{S}\left(i \times n_{i}\right)$

$D_{M}=\frac{S-1}{\ln N}$

$J=\frac{-\sum_{i=1}^{S} p_{i} \ln p_{i}}{\ln S}$

where $i$ is the rank of a taxon (according to its abundance in a sample; most abundant-rank 1), $n_{i}$ is the abundance of taxon $i, S$ is the number of taxa in a sample, $N$ is the total number of specimens, and $p_{i}$ is the proportion of taxon $i$ in a sample.

Dominance structure was analyzed using Czachorowski's classification (Czachorowski 2006). Only Czachorowski's two main classes were taken into account: eudominants (comprising more than $10 \%$ of a sample) and dominants (comprising from $5.1-10 \%$ of a sample). For statistical analysis the two classes were combined into one group of dominants. The following dominance indices were calculated: number of dominant species at a site (DSN), percentage of dominant species at a site (DSSP $=100 \times$ dominant species abundance/sample abundance), and average dominant species abundance at a site $(\mathrm{ADSA}=\mathrm{DSSP} / \mathrm{DSN})$. We also calculated the share of the most abundant species, Alopecosa cuneata, in samples $(\mathrm{AcP}=$ Alopecosa cuneata abundance in sample/total sample abundance).

\section{Statistics}

The relationships between pollution level and diversity and dominance indices were tested with regression analysis, with the soil concentration of zinc ( $\mathrm{mg} \mathrm{Zn} \mathrm{kg}^{-1}$ dry mass, hereinafter referred to as "soil $\mathrm{Zn}$ ") as the independent variable. Zinc was chosen as a sole pollution index because in the previous work in the same area the concentrations of all major metal pollutants in the soil were found to be highly correlated (Stefanowicz et al. 2008). The two transects, xerothermic and mesophilic, were analyzed together, with comparison of intercepts and slopes: a significant difference in intercepts would mean differences in spider biodiversity between the two meadow types with no pollution, while differences in slopes would mean differences in vulnerability to pollution between the spider communities of the two meadow types. The data on $\mathrm{Zn}$ concentrations were taken from Stefanowicz et al. (2008, Table 1) and were $\log _{10}$-transformed. Comparison of intercepts requires both regressions to start from zero on the log-transformed axis, so from each log-transformed concentration we subtracted the zinc concentration level of the control site for that transect. For each transect we assessed the relationships between soil $\mathrm{Zn}$ and the following characteristics of spider communities: (i) total number of spiders; (ii) proportion of juveniles; (iii) biodiversity of mature spiders (HRI, $D_{M}, J$ for each of the three taxonomic levels); (iv) dominance indices (DSN, DSSP, ADSA for each of the three taxonomic levels); and (v) Alopecosa cuneata abundance in the sample vs. total sample abundance (AcP). Then we compared the regression lines between the meadow types by the dummy variable method. This procedure is based on constructing indicator (dummy) variables which allow testing of whether a single model can be used across groups. With only two groups (meadow types) compared, the linear regression model is:

$Y=a_{1}+b_{1} X+I a_{2}+I b_{2} X$

where the indicator variable $I$ takes the value 0 if false (meadow type 1) and 1 if true (meadow type 2). In effect, this procedure fits a separate line for each level of the categorical variable and allows comparison of intercepts and slopes between the levels of that variable. Significance of $a_{2}$ indicates significant differences in intercepts, while significance of $b_{2}$ means significantly different slopes.

All statistical analyses were done with Statgraphics Centurion XV software (Manugistics Company, Rockville, MD, U.S.A.).

\section{Results}

Number of specimens and fraction of juveniles. Species, genus and family richness

In total, 1131 juvenile and 14,135 mature spiders were collected (Table 1). Spiders were more numerous in mesophilic (9036 mature, 608 juveniles; Table 1) than in xerothermic meadows (6264 mature, 524 juveniles; Table 1). There was no clear trend in spider numbers along the pollution gradient. None of the linear regressions for either meadow type were significant ( $p=0.12$ for mature spiders, $p=0.13$ for juveniles). In xerothermic meadows, spiders belonged to 70 species, 36 genera and 16 families, and in mesophilic meadows to 61 species, 32 genera and 14 families (Table 2). There was no clear trend for these values, and no statistical analysis was performed because the number of taxa is better reflected by the Margalef index used in further analyses. 
Table 2 Community structure at research sites

\begin{tabular}{|c|c|c|c|c|c|c|c|}
\hline \multirow[t]{2}{*}{ Site } & \multicolumn{4}{|c|}{ Number of } & \multirow[t]{2}{*}{ DSSP (\%) } & \multirow[t]{2}{*}{ ADSA $(\%)$} & \multirow[t]{2}{*}{$A c \mathrm{P}(\%)$} \\
\hline & $\mathrm{S}$ & G & $\mathrm{F}$ & DSN & & & \\
\hline MX1 & 46 & 28 & 15 & 8 & 60.58 & 7.57 & 14.38 \\
\hline MX2 & 40 & 25 & 13 & 3 & 71.57 & 23.86 & 31.35 \\
\hline MX3 & 40 & 28 & 13 & 4 & 58.75 & 14.69 & 29.98 \\
\hline MX4 & 38 & 23 & 12 & 4 & 73.98 & 18.50 & 52.69 \\
\hline MX6 & 39 & 23 & 12 & 4 & 62.72 & 15.68 & 22.40 \\
\hline MX5 & 47 & 24 & 12 & 4 & 59.56 & 14.89 & 28.90 \\
\hline MM2 & 42 & 26 & 15 & 4 & 76.88 & 19.22 & 13.07 \\
\hline MM4 & 44 & 23 & 14 & 5 & 72.14 & 14.43 & 10.47 \\
\hline MM3 & 45 & 24 & 14 & 7 & 70.10 & 10.01 & 8.36 \\
\hline MM5 & 46 & 26 & 12 & 4 & 63.95 & 15.99 & 31.22 \\
\hline MM6 & 32 & 18 & 11 & 6 & 77.09 & 12.85 & 14.13 \\
\hline
\end{tabular}

$S$ number of species, $G$ genera, $F$ families, DSSP percentage of dominant species at site, DSN number of dominant species at site, average dominant species abundance at site (ADSA $=$ DSSP/DSN), share of the most abundant species at site (AcP)

Sites are ordered from least (low numbers) to most polluted (high numbers) for each transect ( $M X$ xerothermic meadow, $M M$ mesophilic meadow)

Table 3 Biodiversity indices at three taxonomic levels for spider communities along the metal pollution transect

\begin{tabular}{|c|c|c|c|c|c|c|c|c|c|}
\hline & \multicolumn{3}{|l|}{ HRI } & \multicolumn{3}{|c|}{ Margalef index } & \multicolumn{3}{|c|}{ Pielou index } \\
\hline & $\mathrm{S}$ & G & $\mathrm{F}$ & $\mathrm{S}$ & G & $\mathrm{F}$ & $\mathrm{S}$ & G & $\mathrm{F}$ \\
\hline MX1 & 3277 & 2113 & 1111 & 7.34 & 4.41 & 2.28 & 0.81 & 0.77 & 0.6 \\
\hline MX2 & 4104 & 2953 & 1591 & 5.62 & 3.46 & 1.73 & 0.61 & 0.54 & 0.34 \\
\hline MX3 & 2273 & 1491 & 695 & 6.46 & 4.48 & 1.99 & 0.73 & 0.69 & 0.42 \\
\hline MX4 & 6247 & 4291 & 2649 & 4.99 & 2.97 & 1.48 & 0.55 & 0.54 & 0.40 \\
\hline MX6 & 5265 & 3415 & 1660 & 5.55 & 3.21 & 1.61 & 0.73 & 0.73 & 0.47 \\
\hline MX5 & 6285 & 4431 & 2151 & 6.46 & 3.23 & 1.54 & 0.68 & 0.68 & 0.45 \\
\hline MM2 & 5030 & 3344 & 2229 & 5.66 & 3.45 & 1.93 & 0.56 & 0.50 & 0.34 \\
\hline MM4 & 5470 & 3561 & 1955 & 6.26 & 3.20 & 1.89 & 0.7 & 0.70 & 0.53 \\
\hline MM3 & 8460 & 5909 & 2846 & 6.05 & 3.16 & 1.79 & 0.73 & 0.74 & 0.53 \\
\hline MM5 & 9080 & 6451 & 3295 & 5.95 & 3.31 & 1.45 & 0.64 & 0.64 & 0.44 \\
\hline MM6 & 11730 & 7500 & 3690 & 3.93 & 2.15 & 1.27 & 0.68 & 0.62 & 0.32 \\
\hline
\end{tabular}

Sites are ordered from least (lowest numbers) to most polluted (highest numbers) for each transect ( $M X$ xerothermic meadow, $M M$ mesophilic meadow)

$S$ species, $G$ genus, $F$ family

\section{HRI, Margalef and Pielou indices}

The HRI values for all taxonomic levels decreased with increasing soil $\mathrm{Zn}$ in both meadow types (Table 3). Linear regression analyses revealed differences only in intercepts, with lower values for xerothermic habitats, and not in slopes (vulnerability). Under the assumption of equal slopes, the relationships were negative and linear between soil $\mathrm{Zn}$ and HRI for species $(p=0.039)$, genera $(p=0.0041), \quad$ and families $(p=0.0147) \quad$ (Table 2, Figure 1). The significant difference in intercepts for species $(p=0.0145)$, genera $(p=0.0165)$ and families $(p=0.0218)$ show that the two investigated meadow types differed in biodiversity level as described by HRI.

Unlike HRI, the Margalef $D_{M}$ index increased with increasing soil contamination (Table 3). Full linear regression analyses, including slope and intercept comparisons between meadow types, revealed no significant relationship for species $(p=0.575)$ and a marginally significant one for genera $(p=0.0852)$. For the latter case, as the $p$ value was $<0.1$ we repeated the regression analysis assuming equal slopes and intercepts, since there were no differences between the meadow types in this respect. With this assumption the analysis yielded a significant $(p=0.0259)$ 

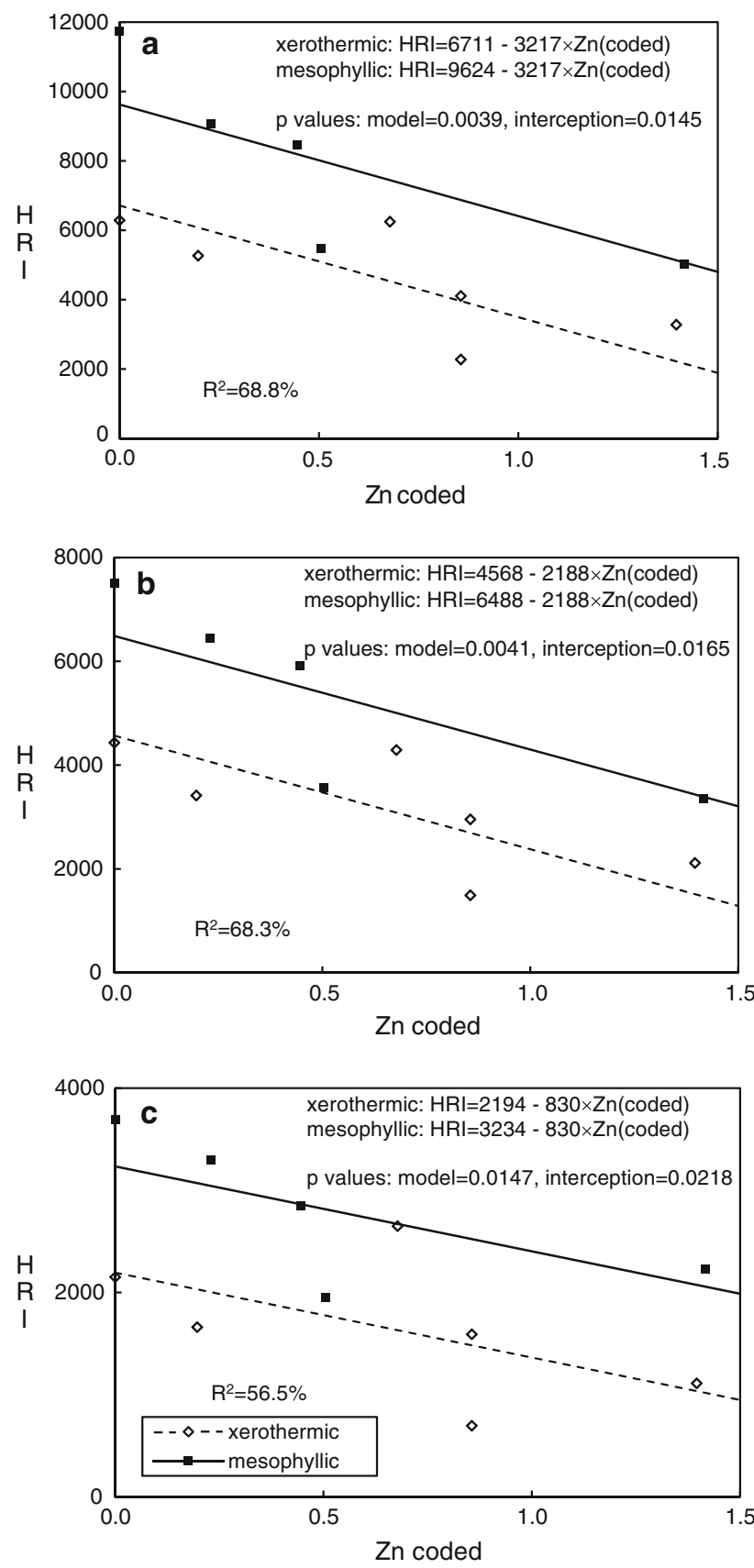

Fig. 1 Relationship between soil Zn and HRI for species (a), genera (b) and families (c) for two types of meadows. For $\mathrm{Zn}$ concentration coding see Methods and Table 1. Slopes were assumed to be equal, as the $p$ values for differences between slopes were 0.36 for species, 0.36 for genera and 0.78 for families

positive relationship between the soil $\mathrm{Zn}$ and $\mathrm{D}_{\mathrm{M}}$ for genera (Table 4, Figure 2). The relationship between $\mathrm{Zn}$ contamination and biodiversity measured at the family level was significant at $p=0.0471$, again with no differences between slopes or intercepts. Consequently, we fit one common regression to both meadow types; this gave slightly higher significance for the relationship $(p=0.028$;
Table 4, Figure 2). The results thus indicated no differences in biodiversity or vulnerability as measured by $D_{M}$ between the two investigated meadow types, and an increase of $D_{M}$ with contamination for families and genera.

There was no significant relationship between soil $\mathrm{Zn}$ and the Pielou (J) index (Table 3). The $p$ values were high for species (0.61), genera (0.70) and families (0.90).

In the raw data we see a slight elevation of almost all indices from the moderately polluted plots (Table 3 ). This may indicate some hormetic effect or confirm intermediate disturbance hypothesis (IDH); we did not test its statistical significance formally but it certainly deserves to be discussed, as will be done further on.

\section{Dominance structure}

In both types of meadows the most dominant species at all 11 sites was Alopecosa cuneata. Also frequent at all sites were Alopecosa pulverulenta and Aulonia albimana. Xerolycosa miniata and Pardosa pullata were noted as dominants in four instances. All these species belong to the Lycosidae family and are considered common and eurytopic. All were numerous in the vicinity of the smelter (Tables 2, 3).

Regression analyses did not show a significant relationship for A. cuneata frequency (AcP; $p=0.33$ ) or for number of dominant species on site (DSN, $p=0.34$ ). Nor did DSSP and ADSA show a relationship to contamination level in either type of meadow $(p=0.36$ and $p=0.64$, respectively; Table 2). Despite the lack of statistical significance, the raw data suggested patterns in both indices for xerothermic meadow: (i) average dominant species abundance (ADSA) decreased, (ii) number of dominant species on site (DSN) increased, and (iii) total species number (S) increased with the increase of pollution (Table 2), except for site MX2 which was more humid than the others. In mesophilic meadows all the indices fluctuated randomly, but the least contaminated site (MM6) showed the fewest species (32) and a high number of dominants (6).

\section{Discussion}

Despite the lack of any relationship between pollution and the total abundance of spiders or the frequency of juveniles, HRI decreased significantly with increasing soil $\mathrm{Zn}$ for all taxonomic levels (species, genera, families). Gargasz (2007) observed the same pattern of diversity measured by HRI in his study of copper- and nickel-contaminated sites in Poland and the UK. Using the Shannon diversity index ( $\left.\mathrm{H}^{\prime}\right)$ in studies of spider communities inhabiting metal-polluted sites in Korea, Jung et al. (2008a) 
also noted a slight, nonsignificant decrease of $H^{\prime}$ with increasing lead and cadmium concentrations, probably because the pollution level was much lower than at the Polish sites: in Korea the highest concentrations were $45.6 \mathrm{mg} / \mathrm{kg} \mathrm{Pb}$ and $1.39 \mathrm{mg} / \mathrm{kg} \mathrm{Cd}$, against $814 \mathrm{mg} / \mathrm{kg} \mathrm{Pb}$ and $20.3 \mathrm{mg} / \mathrm{kg} \mathrm{Cd}$ in Poland. There was no zinc contamination at the Korean sites; in our study area it was the main contaminant. In this context it is worth pointing out that in work done in the Avonmouth area, contaminated with a mixture of metals very similar to that at the Olkusz sites, Spurgeon and Hopkin (1996) concluded that zinc was the main factor responsible for limiting the distribution of earthworms in the surroundings of the smelter.

Besides pollution, the type of habitat also had an important effect on HRI biodiversity, with xerothermic meadows exhibiting lower spider diversity. This is not unexpected: in terms of humidity, temperature amplitude, insolation and flora composition, xerothermic meadows are harsher environments (Clements and Newman 2002). Such places are characterized by relatively high natural environmental stress, which limits biodiversity and steers communities towards fewer but more specialized species.

Unlike HRI, Margalef $\mathrm{D}_{\mathrm{M}}$ increased with pollution level for genera and families. No trend for species $D_{\mathrm{M}}$ was found, and there were no differences between meadow types. Gautman et al. (2006) reported similar results in a study of five arthropod orders. They noted the highest Coleoptera species richness at polluted industrial sites, and six of the species they collected were found only at such sites. Fountain and Hopkin (2004a) confirmed the same pattern for Collembola communities in polluted areas. One explanation of this fairly consistent pattern might be that pollutant-caused changes in environmental conditions can lead to the emergence of new niches for new species, as described in detail in work on sulphur dioxide and Heteroptera (Brändle et al. 2001, 2006): higher $\mathrm{SO}_{2}$ deposition had altered the soil conditions, making it possible for new species of plants to appear in the area. In turn, the new plant species provided a food source for new monophagous species of Heteroptera, and new herbivore arthropods attracted new narrowly specialized arthropod predators. Other explanation is that more resistant new species may appear in contaminated areas and outcompete species inhabiting parts of niches. The frequency of rare species can increase, as clearly reflected in the dominance structure we uncovered. More work is needed to confirm whether newcomers and certain rare species are indeed more resistant to pollution and can compete more successfully in harsh environments. Gargasz (2007) obtained different results in copper- and nickel-polluted areas, where $\mathrm{D}_{\mathrm{M}}$ for genera decreased with increasing pollution. Again, the explanation may be higher copper toxicity (Pedersen et al. 1999).
At moderately polluted sites the Pielou (J) and HRI indices increased slightly, probably due to a stimulatory, hormetic effect of low stress. In the same area a similar hormetic effect was described in oribatid mites (Skubała and Kafel 2004). Under moderate pollution, organisms may not only efficiently repair any toxicant-caused damage but also overcompensate the disturbance with elevated vitality and fitness (Calabrese and Baldwin 2002; Chapman 2002). The increased Pielou index in our study may have a simpler explanation. At the moderately polluted sites the fraction of dominants decreased; recedent species may cope more efficiently with concurrent species in such a changed setting. As a result their fraction increases, evening out the distribution of individuals among species. A particular type of hormesis has been seen under other kinds of anthropogenic stresses: biodiversity was slightly higher in environments that were moderately physically disturbed (and not polluted) than in natural conditions. These disturbances involved agriculture and landscape changes (Jung et al. 2008a) or urbanization (Alaruikka et al. 2002). The effect was originally suggested in the intermediate disturbance hypothesis (IDH), describing a phenomenon found in work on rainforest spider biodiversity (Connell 1978). Elevated biodiversity in areas with dense field boundaries fits this category of explanation (Haughton et al. 1999), though not disturbance but rather high landscape tessellation is responsible here.

In this analysis neither the abundance of adult spiders nor the fraction of juveniles were related to the pollution level. Gargasz (2007) found that adult spider abundance decreased significantly with increasing pollution level in the vicinity of copper and nickel smelters, and a number of studies of other groups of invertebrates have shown abundance decreasing with pollution level, for example in Lumbricidae, Enchytreidae and microarthropods (Lukkari et al. 2003). The discrepancy between those studies and ours may be due to differences in sampling methods, field conditions, groups of investigated animals, or type of pollution. All the taxonomic groups in those papers except for the one examining spiders (Gargasz 2007) are soildwelling animals, and as such are exposed to contaminants not only through food but directly through soil solution. It is known that metals basically are toxic only when they occur in dissolved ionic forms (Fountain and Hopkin 2004a), so animals exposed through soil solution are more exposed to their toxicity. Also the type of metal is important, as shown in a number of studies. Zinc and lead exhibit relatively low toxicity in invertebrates, and cadmium, although more toxic, is usually present at low concentrations even in highly polluted soils (Hopkin and Hames 1994). Gargasz (2007) made his studies in a copper mining and smelting area where the main pollutant was $\mathrm{Cu}$. Although essential at low concentrations, this metal is 
Table 4 Linear regression analysis of relationships between soil $\log (\mathrm{Zn})$ and community diversity indices

\begin{tabular}{lllll}
\hline & Taxonomic level & & $\mathrm{F}$ & $p$-value \\
\hline HRI & Species & Model & 12.03 & 0.0039 \\
& & Intercept difference & 9.66 & 0.0145 \\
& \multirow{2}{*}{ Genus } & $\mathrm{R}^{2}$ & $68.8 \%$ & \\
& & Model & 11.77 & 0.0041 \\
& & Intercept difference & 9.14 & 0.0165 \\
& Family & $\mathrm{R}^{2}$ & $68.3 \%$ & \\
& & Model & 7.5 & 0.0147 \\
& & Intercept difference & 8.07 & 0.0218 \\
& & $\mathrm{R}^{2}$ & $56.5 \%$ & \\
Margalef index & Genus & Model & 7.09 & 0.0259 \\
& & $\mathrm{R}^{2}$ & $37.9 \%$ & \\
& Family & Model & 16.58 & 0.0028 \\
& & $\mathrm{R}^{2}$ & $60.9 \%$ & \\
& & & &
\end{tabular}

Only regressions significant at $p \leq 0.05$ are reported

$H R I$ hierarchical richness index
Although we concentrated so far on possible direct effects of pollution on spider communities, it should be stressed that also a range of secondary, indirect effects are possible.

Relationships between organisms in a community may be massively influenced without any direct effects on certain groups (Lefcort et al. 2002) and can lead to unpredictable changes at the community level (Geiszinger et al. 2009). These phenomena are of particular interest in modern ecotoxicology and ecological risk assessment (Arapis 2005), but are still poorly recognized, and available data focus mainly on aquatic ecosystems (Fleeger et al. 2003).

In food webs spiders are predators, prey and competitors. The spiders investigated herein are general epigeic predators which feed mostly on collembolans, hymenopterans and hemipterans what places them in the detritus and grazer food webs (Nentwig 1982; Foelix 1996). Both of these webs are affected by metal pollution, and it was reported in many studies that potential prey of the spiders can be directly affected by metals, what results in a decrease of their abundance (e.g., Fountain and Hopkin 2004a, Nahmani and Rossi 2003). The lack of prey can be, in turn, reflected in the decrease of predators' numbers what would result in patterns similar to those observed in this study for spiders.

Indirect effect on competition in terms of species reordering within epigeic Araneae group was briefly mentioned in the first part of discussion. It can involve, however, also other competitors. The main ground-dwelling spiders' competitors are coleopterans, especially Staphylinidae and Carabidae families. Carabids were investigated in the same research area and showed similar pattern of changes in biodiversity (Skalski et al. 2010) as epigeic spiders. This observation suggests that indirect effects via competition 
with carabids probably did not occur, but effects of other competitors cannot be excluded.

The present study does not allow for separating direct and indirect effects of metal pollution on epigeic spiders. However, significant effects of pollution on spider communities have been proved and further research would be required to find out exact causes of the observed patterns.

\section{Conclusions}

1. HRI-measured diversity for species, genera and families significantly decreased with metal pollution level in both xerothermic and mesophilic meadows. Diversity differed between the two meadow types. There were no differences in the vulnerability of spider communities to contamination.

2. The Margalef index for genera and families increased with increasing contamination.

3. There was evidence for hormesis or the intermediate disturbance hypothesis.

4. No statistically significant changes in the dominance structure were found, but in xerothermic meadows there was some increase of total species number and dominant species number at heavily polluted sites.

5. Metal pollution did not affect the Pielou index.

6. Metal pollution did not affect spider abundance or the fraction of juveniles.

7. Of the indexes applied, HRI was the one most sensitive to the effects of pollution on community structure at different levels of taxonomic resolution.

8. Spiders community may be affected by heavy metals not only directly, but also by indirect effect of pollutants.

Acknowledgments The authors would like to thank Dr Paulina Kramarz and Dr Irena Grześ for help in fieldwork. This research was financially supported by the European Union under the 6th Framework Programme (project acronym ALARM, contract number GOCE-CT-2003-506675).

Open Access This article is distributed under the terms of the Creative Commons Attribution License which permits any use, distribution, and reproduction in any medium, provided the original author(s) and the source are credited.

\section{References}

Alaruikka D, Kotze JD, Matveinen K, Niemel J (2002) Carabid beetle and spider assemblages along a forested urban-rural gradient in southern Finland. J Insect Conserv 6:195-206

Arapis G (2005) Modern problems of ecotoxicology. Ecotoxicology 6:101-109

Babczyńska A, Wilczek G, Migula P (2006) Effects of dimethoate on spiders from metal pollution gradient. Sci Total Environ 370:352-359
Brändle M, Amarell U, Auge H, Klotz S, Brand R (2001) Plant and insect diversity along a pollution gradient: understanding species richness across trophic levels. Biodivers Conserv 10:1497-1511

Calabrese EJ, Baldwin LA (2002) Defining hormesis. Hum Exp Toxicol 21:91-97

Chapman P (2002) Ecological risk assessment (ERA) and hormesis. Sci Total Environ 288:131-140

Clements WH, Newman MC (2002) Community ecotoxicology. Wiley, New York

Connell JH (1978) Diversity in tropical rain forest and coral reefs. High diversity of trees and corals is maintained only in a nonequilibrium state. Science 199:1302-1310

Creamer RE, Rimmer DL, Black HIJ (2008) Do elevated soil concentrations of metals affect the diversity and activity of soil invertebrates in the long-term? Soil Use Manag 24:37-46

Czachorowski S (2006) Opisywanie biocenozy-zoocenologia. Skrypt elektroniczny dla magistrantów. http://www.uwm.edu.pl/cza chor/publik/pdf-inne/zoocenozy.pdf

Duelli P, Obrist MK (1998) In search of the best correlates for local organismal biodiversity in cultivated areas. Biodivers Conserv 7:297-309

Fleeger JW, Carman KR, Nisbet RM (2003) Indirect effects of contaminants in aquatic ecosystems. Sci Total Environ 317:207-233

Foelix R (1996) Biology of spiders. Oxford University Press, New York, pp 232-233

Fountain M, Hopkin S (2004a) A comparative study of the effect of metal contamination on Collembola in the field and in the laboratory. Ecotoxicology 13:573-597

Fountain M, Hopkin S (2004b) Biodiversity of Collembola in urban soils and the use of Folsomia candida to assess soil "quality". Ecotoxicology 13:555-572

French D, Lindley D (2000) Statistics in ecotoxicology. Wiley, New York

Gallagher F, Pechmann I, Bogden JD, Grabosky J, Weis P (2008) Soil metal concentrations and productivity of Betula populifolia (gray birch) as measured by field spectrometry and incremental annual growth in an abandoned urban Brownfield in New Jersey. Environ Pollut 156:699-706

Gargasz K (2007) Bioróżnorodność pająków (Araneae) epigeicznych na terenach zanieczyszczonych przez huty miedzi i niklu M.Sc. thesis, Jagiellonian University, Kraków

Gautam J, Misra KK, Bhattacharya T (2006) Diversity of some insect fauna in industrial and non-industrial areas of West Bengal, India. J Insect Conserv 10:249-260

Geiszinger A, Bonnineau C, Faggiano L et al (2009) The relevance of the community approach linking chemical and biological analyses in pollution assessment. Trends Anal Chem 28:619-626

Giller KE, Witter E, McGrath SP (1998) Toxicity of heavy metals to microorganisms and microbial processes in agricultural soils: a review. Soil Biol Biochem 30:1389-1414

Haughton AJ, Bell JR, Boatman ND, Wilcox A (1999) The effects of different rates of the herbicide glyphosate on spiders in arable field margins. J Arachnol 27:249-254

Hendrickx F, Maelfait JP, Bogaert N, Tojal C, Du Laing G, Tack FM, Verloo MG (2004) The importance of biological factors affecting trace metal concentration as revealed from accumulation patterns in co-occurring terrestrial invertebrates. Environ Pollut 127:335-341

Hopkin SP, Hames CAC (1994) Zinc, among a cocktail of metal pollutants, is responsible for the absence of the terrestrial isopod Porcellio scaber from the vicinity of a primary smelting works. Ecotoxicology 3:68-78

Jung M-P, Seung-Tae K, Hunsung K, Lee J-H (2008a) Biodiversity and community structure of ground-dwelling spiders in four different field margin types of agricultural landscape in Korea. Appl Soil Ecol 38:185-195 
Jung M-P, Seung-Tae K, Hunsung K, Lee J-H (2008b) Species diversity and community structure of ground-dwelling spiders in unpolluted and moderately heavy metal-polluted habitats. Water Air Soil Pollut 195:15-22

Kajak A, Andrzejewska L, Wojcik Z (1968) The role of spiders in the decrease of damages caused by Acridoidea on meadows: experimental investigations. Ekologia Polska 26:755-764

Kapoor V (2008) Effects of rainforest fragmentation and shade-coffee plantations on spider communities in the Western Ghats, India. J Insect Conserv 12:53-68

Kramarz P, Laskowski R (1997) Effect of zinc contamination on life history parameters of a ground beetle, Poecilus cupreus. B Environ Contam Toxicol 59:525-530

Łagisz M, Kramarz P, Laskowski R, Tobor M (2002) Population parameters of the beetle Pterostichus oblongopunctatus F. from metal contaminated and reference areas. Arch Environ Contam Toxicol 69:243-249

Laskowski R, Kammenga J (2000) Demography in ecotoxicology. Wiley, New York

Lefcort H, Aguon MQ, Bond KA et al. (2002) Indirect effects of heavy metals on parasites may cause shifts in snail species compositions. Arch Environ Contam Toxicol 43:34-41

Lukkari T, Taavitsainen M, Väisänen A, Haimi J (2003) Effect of heavy metals on earthworms along contamination gradients in organics rich soils. Ecotoxicol Environ Safe 59:340-348

Marc P, Canard A (1997) Maintaining spider biodiversity in agroecosystems as a tool in pest control. Agric Ecosyst Environ 62:229-235

Marc P, Canard A, Ysnel F (1999) Spiders (Aranea) useful for pest limitation and bioindication. Agric Ecosyst Environ 74:229273

Midega CAO, Khan ZR, van den Berg J, Ogol CKPO, DippenaarSchoeman AS, Pickett JA, Wadhams LJ (2008) Response of ground-dwelling arthropods to a 'push-pull' habitat management system: spiders as an indicator group. J Appl Entomol 132: 248-254

Możdżer JT, Kramarz P, Piśkiewicz A, Niklińska M (2003) Effects of cadmium and zinc on larval growth and survival in the ground beetle, Pterostichus oblongopunctatus. Environ Int 28:737-742

Nahmani J, Rossi J-P (2003) Soil macroinvertebrates as indicators of pollution by heavy metals. C R Biol 326:295-303

Nentwig W (1982) Oecologia epigeic spiders, their potential prey and competitors: relationship between size and frequency. Oecologia 55:130-136

Nentwig W, Blick T, Gloor D, Hänngi A, Kropf K (2011) Araneae spiders of Europe. http://www.araneae.unibe.ch

Nieuwenhuys E (2011) Spiders of Europe, Australia and some immunology. http://ednieuw.home.xs4all.nl/

Niklińska M, Laskowski R, Maryański M (1998) Effect of heavy metals and storage time on two types of forest litter: basal respiration rate and exchangeable metals. Ecotoxicol Environ Safe 41:8-18

Oxbrough AG, Gittings T, O’Halloran J, Giller PS, Kelly TC (2007) Biodiversity of ground-dwelling spiders' fauna of afforestation habitats. Agric Ecosyst Environ 120:433-441
Pedersen Bruus M, Axelsen J, Strandberg B, Jensen J, Attril M (1999) The impact of a copper gradient on a microarthropod field community. Ecotoxicology 8:467-483

Platnick NI (2011) The world spider catalog version 12.0. http:// www.research.amnh.org/entomology/spiders/catalog

Posthuma L, van Stralen NM (1993) Heavy-metal adaptation in terrestrial invertebrates: a review of occurrence, genetics, physiology and ecological consequences. Comp Biochem Physiol C 106:11-38

Roberts MJ (1995) Spiders of Britain \& Nothern Europe. Harper Collins Publishers, London

Sackett TE, Buddle CM, Vincent C (2008) Relevance of collected juveniles to the analysis of spider communities. J Arachnol 36:187-190

Salminen J, Anh BT, van Gestel CAM (2001) Indirect effects of zinc on soli microbes via a keystone enchytraeid species. Environ Toxicol Chem 20:1167-1174

Sauberer N, Zulka KP, Abensperg-Traun M, Berg H-M, Bieringer G, Milasowszky N, Moser D, Plutzar C, Pollheimer M, Storch C, Tröstl R, Zechmeister H, Grabherr G (2004) Surrogate taxa for biodiversity in agricultural landscapes of eastern Austria. Biol Conserv 117:181-191

Schmidt MH, Thies C, Nentwig W, Tscharntke T (2008) Contrasting responses of arable spiders to the landscape matrix at different spatial scales. J Biogeogr 35:157-166

Sibly RM, Calow P (1989) A life-cycle theory of responses to stress. Biol J Linn Soc 37:101-116

Skalski T, Stone D, Kramarz P, Laskowski R (2010) Ground beetle community responses to heavy metal concentration. Balt $\mathrm{J}$ Coleopterol 10:1-12

Skubała P, Kafel A (2004) Oribatida mite communities and metal bioaccumulation in oribatid species (Acari, Oribatida) along the heavy metal gradient in forest ecosystems. Environ Pollut 132:51-60

Spurgeon DJ, Hopkin SP (1996) The effects of metal contamination on earthworm populations around a smelting works: quantifying species effects. Appl Soil Ecol 4:147-160

Stefanowicz AM, Niklińska M, Laskowski R (2008) Metals affect soil bacterial and fungal functional diversity differently. Environ Toxicol Chem 27:591-598

Tischer S (2005) Lumbricids species diversity and heavy metal amounts in lumbricids on soil monitoring sites in Saxony-Anhalt (Germany). Arch Agron Soil Sci 51:391-403

Tyler G (1976) Heavy metal pollution, phosphatase activity, and mineralization of organic phosphorus in forest soils. Soil Biol Biochem 8:327-332

Wilczek G, Babczyńska A, Migula P, Wencelis B (2003) Activity of esterases as biomarkers of metal exposure in spiders from the metal polluted gradient. Pol J Environ Stud 12:765-771

Wilczek G, Babczyńska A, Augustyniak M, Migula P (2004) Relations between metals $(\mathrm{Zn}, \mathrm{Pb}, \mathrm{Cd}$ and $\mathrm{Cu})$ and glutathione-dependent detoxifying enzymes in spiders from a heavy metal pollution gradient. Environ Pollut 132:453-461

Willet TR (2001) Spiders and other arthropods as indicators in oldgrowth versus logged redwood stands. Restor Ecol 9:410-420 